ISPEC Tarım Bilimleri Dergisi

$2020: 4(2)$

(C) Telif hakk ISPEC'e aittir

Arastırma Makalesi

\section{* Erdal ERBíL}

Orcid No: 0000-0001-6044-5165

*GAP Tarımsal Araştırma Enstitüsü Müdürlüğü, Şanlıurfa

erdal.erbil@tarimorman.gov.tr

DOI

https://doi.org/10.46291/ISPECJASv

ol4iss2pp137-149

Geliş Tarihi: 01/03/2020

Kabul Tarihi: $\quad 27 / 05 / 2020$

\section{Anahtar Kelimeler}

Soya, ikinci ürün, verim Şanlıurfa, protein, ham yağ

\section{Keywords}

Soybean, second crop, yield, Şanlıurfa, protein, crude oil

\title{
www.ispecjournal.com
}

\section{Bazı İleri Soya (Glycine max. L.) Hatlarının Şanlıurfa İkinci Ürün Koşullarında Verim ve Kalite Özellikleri Yönünden Değerlendirilmesi}

\section{Özet}

$\mathrm{Bu}$ çalışma, bazı ileri soya hatlarının Şanlıurfa ikinci ürün koşullarında performanslarının belirlenmesi amacıyla 2018-2019 yıllarında yürütülmüştür. Çalışmada, melezleme yöntemiyle geliş̧tirilmiş olan 12 ileri hat (Antjc-17,Antwa-20, Antwa-4, Antjc14, Batem-210, Antjc-15, Antwa-2, Batem-204, Batem-316, Antsoy-2, Antjc-20, Antjc-23) ve 3 standart çeşit (Kocatürk, Göksoy, Adasoy) materyal olarak kullanılmıştır. Araştırma, GAP Tarımsal Araştırma Enstitüsü Gündaş Araştırma istasyonunda 2018-2019 y1llarında iki yıl üst üste yürütülmüştür. Araştırmada, çiçeklenme gün sayısı, fizyolojik olgunluk gün sayısı, bitki boyu, ilk bakla yüksekliği, verim ve bin tane ağırlığı gibi morfolojik özelliklerin yanında ham protein ve ham yağ gibi kalite özellikleri de incelenmiştir. Araştırma sonuçlarına göre; bitkide ilk bakla yüksekliği $(\mathrm{p}<0.05)$ dışında incelenen tüm özellikler bakımından soya hatları arasında istatistik olarak oldukça önemli $(\mathrm{p}<0.01)$ farklar tespit edilmiştir. İncelenen soya genotiplerin arasında tane verimi $171,4-560,1 \mathrm{~kg}$ da-1 bitki boyu $67.6-126,6 \mathrm{~cm}$, ham protein oranı \%28.9 ile 39.9 , ham yağ oranı \%18.1 ile 23.6 ve bin tane ağırlığı 125,8-179,4 gr arasında değişmiştir.

Evaluation of Some Advanced Soybean (Glycine max. L.) Lines in Terms of Yield and Quality Properties in Şanlıurfa Second Crop Conditions

\section{Abstract}

This study was carried out to determine the performance of some advanced soybean lines under Şanlıurfa second product conditions in 2018-2019 years. In study, 12 advanced lines developed by hybridization method (Antjc-17, Antwa-20, Antwa-4, Antjc-14, Batem-210, Antjc-15, Antwa-2, Batem-204, Batem-316, Antsoy-2, Antjc-20, Antjc-23) and 3 standard types (Kocatürk, Göksoy, Adasoy) were used as materials. The research was carried out for two consecutive years at the GAP Agricultural Research Institute Gündaş Research station in 2018-2019. In the study, morphological features such as number of flowering days, physiological maturity days, plant height, first pod height, yield, and thousand grain weight, as well as quality features such as crude protein and crude oil were investigated. According to the research results; There were statistically significant $(p<0.01)$ differences between the soybean lines in terms of all features studied except for the first pod height ( $\mathrm{p}<0.05$ ). Among the soy genotypes examined, grain yield is $171.4-560.1 \mathrm{~kg}$ da-1 plant height $67.6-126.6 \mathrm{~cm}$, crude protein ratio is $28.9 \%$ and $39.9 \%$, crude oil ratio is $18.1 \%, 23.6 \%$ and thousand grain weight is $125.8-174.4 \mathrm{~g}$ ranged from. 


\section{GíRIŞ}

Baklagiller familyasından olan soya; dünyada en önemli endüstri bitkilerindendir. Soya tohumu içermiş olduğu \% 18-22 yağ ve \% 40-42 protein bakımından insan beslenmesinde önemli bir yere sahiptir (Çopur ve ark., 2009). Soya, hem topraktan kaldırdığ 1 azotu hem de Bradyrhizobium japonicum bakterileri vasitasıyla atmosferden fiske ettiği azotu kullanabilme yeteneğine sahip bir bitkidir (Söğüt, 2005). Soya bitkisinin büyüme ve gelişmesi çevre koşullarından çok fazla etkilenmekte, fotoperyoda tepkileri çeşitlere göre farkl1lık göstermektedir (Zhang ve ark. 2001). Fotoperyoda tepkilerine göre soya çeşitleri ekvatorun kuzeyinden başlamak üzere, kutuplara doğru 12 değişik yetişme grubu içerisinde sınıflandırılmaktadır. Genel olarak kısa gün bitkisi olarak tanımlanan soya, uzun gün koşullarında daha fazla sayıda çiçek oluşturmakta, ancak çiçek silkme oranı artmaktadır(Arıoglu, 2000). Soya tarımında birim alandan elde edilen verim; kullanılan çeşide ve uygulanan kültürel yöntemlere ve ekolojik şartlara göre değişmektedir (Uncu ve Arığlu, 2005). Islah çalışmalarında verim kriterlerinin yanında erkencilikte önem arz etmektedir. Erken olgunlaşan genotipler farklı çevre koşullarına kendilerini daha iyi adapte ederler. $\mathrm{Bu}$ çeşitler, tane verimine etkili olan çiçeklenmeye ve tane olumuna kadar geçen süreye daha uygun zamanda erişirler (Önemli ve Atakişi, 2001). Günümüzde yeni geliştirilen soya çeşitlerinde yalnızca verim ve verim kriterleri üzerinde değil, protein, aminoasitler, yağ ve yağ asitleri gibi kalite ölçütleri üzerinde de önemle durulmaya başlanmıştır. Soyada tescil edilecek genotiplerin tane veriminin yanında yüksek yağ ve protein oranlarına da sahip olması istenmektedir. Fakat, soyada yağ ve protein oranları arasında ters bir korelasyon bulunduğundan (Cober ve Voldeng, 2000), yüksek verim ile birlikte yüksek yağ ve protein oranlarının bir çeşitte bulunması pek olası görünmemektedir. Yeni çeşitler geliştirilirken, şartlara göre öncelikleri belirleyip bu yönde çeşit sslah çalışmalarına yön verilmesi önem arz etmektedir. Islah çalışmalarıyla verim ve tarımsal özellikler bakımından üstün olan yeni çeşitler geliştirilmektedir. Geliştirilen yeni hat veya çeşitlerin farklı ekolojik koşullarda değişik sonuçlar vereceği bilimsel bir gerçekliktir. $\mathrm{Bu}$ nedenle, bölgesel adaptasyon çalışmaları, özellikle yeni çeşit veya hatlar için önemli bir sslah aşamasıdır. Çeşit geliştirme programlarında başarının temel stratejilerden ilki, bölge 
koşullarında çalışılan bitkide verim ve kaliteyi tanımlayan ölçütlerin birbirleriyle interaksiyonlarının 1slahçı tarafından iyi kavranmasıdır (Poehlman, 1979).

$\mathrm{Bu}$ çalışma; melezleme yoluyla elde edilmiş ileri hatların Şanlıurfa ikinci ürün koşullarında performanslarını belirleyerek bölgeye uygun erkenci ve yüksek verimli çeşit adaylarını belirmek amacıyla yürütülmüştür.

\section{MATERYAL ve YÖNTEM}

Araştırma 2018-2019 yıllarında üst üste iki yıl ikinci ürün yetiştirme sezonunda Şanlıurfa GAP Tarımsal Araştırma Enstitüsü Müdürlüğüne bağlı Gündaş deneme istasyonunda tesadüf blokları deneme desenine göre üç tekerrürlü olarak yürütülmüş̧tür. Araştırmada bitki materyali olarak Antalya Batı Akdeniz Tarımsal Araştırma Enstitüsünden temin edilen 12 ileri hat ve standart olarak da Kocatürk, Göksoy ve Adasoy çeşitleri kullanılmıştır. Deneme alanında ön bitki olan buğday üretimden sonra derin sürüm yapılmış daha sonra yağmurlardan sonra kültivatör ve tapan çekilerek tavlı toprak ekime hazır hale getirilmiştir. Her sırada 125 bitki olacak şekilde tohum hesabı ile parsellerin alanı deneme mibzer ile ekimde $0.7 \times 4=2.8 \mathrm{~m}^{2}$ olarak ayarlanmıştır. Deneme ekimleri 15 Haziran'da yapılmıştır. Araştırma alanı toprak analiz sonuçları çizelge 1 de verilmiştir.

Çizelge 1. Araştırmanın yürütüldüğü Gündaş istasyonunun toprak özellikleri

\begin{tabular}{lll}
\hline \multirow{2}{*}{ Lokasyon } & \multicolumn{2}{c}{ Gündaş } \\
\cline { 2 - 3 } Derinlik (cm) & $\mathbf{0 - 3 0}$ & $\mathbf{3 0 - 6 0}$ \\
\hline Ec $(\mathrm{dS} \mathrm{m})$ & 0.71 & 0.69 \\
$\mathrm{pH}$ & 7.90 & 7.80 \\
Kireç oranı (\%) & 18.60 & 17.90 \\
Toplam P (kg/da) & 5.43 & 5.45 \\
Toplam K (kg/da) & 273.60 & 270.20 \\
Organik madde oranı $(\%)$ & 0.91 & 0.83 \\
$\mathrm{Cu}\left(\mathrm{mg} \mathrm{kg}^{-1}\right)$ & 1.13 & 1.08 \\
$\mathrm{Mn}\left(\mathrm{mg} \mathrm{kg}^{-1}\right)$ & 4.57 & 4.35 \\
$\mathrm{Fe}\left(\mathrm{mg} \mathrm{kg}^{-1}\right)$ & 4.56 & 4.50 \\
$\mathrm{Zn}\left(\mathrm{mg} \mathrm{kg}^{-1}\right)$ & 1.30 & 1.20 \\
\hline
\end{tabular}

Ekimle birlikte parsellere $6 \mathrm{~kg} / \mathrm{da}$ saf $\mathrm{N}$ ve $\mathrm{P}_{2} \mathrm{O}_{5}$ 20-20-0 kompoze gübre formunda verilmiştir. Üst gübrelemede dekara $4 \mathrm{~kg}$ saf olacak şekilde $\mathrm{N}(\% 21 \mathrm{AS})$ formunda verilmiştir. Araştırmada dar ve geniş yapraklı yabancı otlara karşı herbisit ve kırmızı örümceğe karşı akarisit ilaçlaması yapılmıştır. Sezon sonuna kadar 8 defa 
sulama yağmurlama sulama şekilde verilmiştir. Parsellerin başından ve sonundan $0.5 \mathrm{~m}$ alınmış ve hasat, deneme biçerdöveri ile 1.4 x $5=7 \mathrm{~m}^{2}$ üzerinden baklaların tam olgunlaşma döneminde yapılmıştır. Araştırmanın yürütüldüğü Gündaş istasyonu 2019 yılı ve uzun yıllar iklim özellikleri çizelge 2 de verilmiştir.

Çizelge 2. Yetiştirme sezonları ve uzun yıllar Gündaş istasyonu iklim verileri (Anonim, 2020)

\begin{tabular}{|c|c|c|c|c|c|c|c|c|c|c|}
\hline \multirow[b]{2}{*}{ Aylar } & \multicolumn{2}{|c|}{$\begin{array}{c}\text { Ort. } \\
\text { Sicaklık } \\
\left({ }^{\circ} \mathrm{C}\right) \\
\end{array}$} & \multicolumn{2}{|c|}{$\begin{array}{c}\text { En yüksek sıcaklık } \\
\left({ }^{\circ} \mathrm{C}\right)\end{array}$} & \multicolumn{2}{|c|}{$\begin{array}{c}\text { En düşük sıcaklık } \\
\left({ }^{\circ} \mathrm{C}\right)\end{array}$} & \multicolumn{2}{|c|}{$\begin{array}{c}\text { Toplam yağış (kg } \\
\left.\mathbf{m}^{2}\right)\end{array}$} & \multicolumn{2}{|c|}{$\begin{array}{c}\text { Ort. nisbi } \\
\text { nem } \\
(\%) \\
\end{array}$} \\
\hline & 2018 & 2019 & 2018 & 2019 & 2018 & 2019 & 2018 & 2019 & 2018 & $\begin{array}{c}201 \\
9\end{array}$ \\
\hline Haziran & 27.1 & 28.3 & 37.9 & 36.8 & 18.3 & 18.0 & 2.0 & 1.0 & 35.9 & 30.2 \\
\hline Temmu & 32.6 & 33.1 & 40.4 & 39.8 & 20.0 & 21.4 & -- & 0.6 & 42.9 & 41.6 \\
\hline Ağustos & 33.4 & 34.0 & 41.7 & 39.0 & 21.2 & 20.8 & 1.1 & 0.9 & 45.1 & 35.7 \\
\hline Eylül & 25.4 & 26.9 & 34.2 & 34.7 & 16.4 & 15.6 & 1.4 & 13.3 & 44.9 & 47.4 \\
\hline Ekim & 21.7 & 19.4 & 24.5 & 26.9 & 14.0 & 14.4 & 12.8 & 19.1 & 51.3 & 58.6 \\
\hline & 28.04 & 28.34 & 35.74 & 35.44 & 17.98 & 18.04 & 4.32 & 6.98 & 44.0 & 42.7 \\
\hline
\end{tabular}

\section{BULGULAR ve TARTIŞMA}

Şanlıurfa ikinci ürün koşullarında araştırmaya alınan soya genotiplerinin incelenen tüm özellikler yönünden her iki yılda da aralarındaki farklar istatistiksel olarak önemli bulunmuştur. Çizelge 3.'deki y1l ortalamaları ve LSD istatistiksel gruplandırma incelendiğinde, 2018 yılında çiçeklenme gün sayıları ortalama 38.9-42.7 gün arasında değişmiş olduğu görülmektedir. 2019 yılında çiçeklenme gün sayıları ortalama 37.7-40.7 gün arasında değişmiş, araştırmanın her iki y1lında da en erken çiçeklenme Antwa-2 genotipi olmak üzere, en geç çiçeklenen genotip ise Batem-316 olmuştur. Kolay
(2007), Diyarbakır II. Ürün koşullarında soyada çiçeklenmenin ortalama 35 ile 38.2 gün arasında değiştiğini bildirmiştir. Dolapçı (2012), Kahramanmaraş’ta ana ürün koşullarında yaptığg araştırmada en erken çiçeklenme ekimden yaklaşık 45 gün sonra Nova çeşidinde görüldüğünü, en geç çiçeklenmenin ise ekimden yaklaşık 67 gün sonra ile Yemsoy çeşidinden elde edildiğini bildirmiştir. Soyada gün uzunluğundaki farklılıkların çiçeklenme başlangıcı ve gelişimini etkilediği ve bu etkinin çeşitlere veya yetiştiği bölgeye göre farklılıklar gösterdiği belirlenmiştir (Wigham ve Minor, 1978; Zhang ve ark., 2001). 2018 yılında fizyolojik olgunluk gün sayıları 
ortalama 119.2-135 gün arasında değişmiş, 2016 yılında çiçeklenme gün sayıları ortalama 117.3-131 gün arasında değişmiştir. Her iki yılda da en erken Antwa-2 genotipi fizyolojik olgunluğa erişen çeşit olup, Adasoy çeşidi hasat olgunluğuna en geç ulaşan çeşit olmuştur.
Elde edilen bulgular Y1lmaz ve ark. (2005), Güneş (2006), Çetin (2010), Dolapçı (2012)'nın bulgulariyla tam olarak uyum içinde olup, Ünal (2007), Erdoğmuş (2007), Arslan (2007) ve Malik ve ark. (2011) 'in bulgularıyla da kısmen uyumludur.

Çizelge 3. Çiçeklenme gün sayısı fizyolojik olgunluk gün sayısı ve bitki boyu özellikleri

\begin{tabular}{|c|c|c|c|c|c|c|}
\hline \multirow[b]{2}{*}{ Genotipler } & \multicolumn{2}{|c|}{ Çiçek. Gün. Sayısı*** } & \multicolumn{2}{|c|}{ Fiz.Olg.Gün. Say** } & \multicolumn{2}{|c|}{ Bitki Boyu** } \\
\hline & 2018 & 2019 & 2018 & 2019 & 2018 & 2019 \\
\hline Adasoy & $42.0 \mathrm{~B}$ & $40.0 \mathrm{AB}$ & $135 \mathrm{~A}$ & $131 \mathrm{~A}$ & $79.8 \mathrm{H} \mathrm{I}$ & $67.6 \mathrm{I}$ \\
\hline Antjc-14 & 39.7 DEF & 38.7 CDEF & $126 \mathrm{DE}$ & $123 \mathrm{C} \mathrm{D} \mathrm{E}$ & $89.3 \mathrm{GH}$ & $86.3 \mathrm{GH}$ \\
\hline Antjc-15 & $40.3 \mathrm{CD}$ & 39.3 BCD & $125.3 \mathrm{DE}$ & 123.3 C D E & $121.6 \mathrm{~A}$ & $123.3 \mathrm{~A} \mathrm{~B}$ \\
\hline Antjc-17 & $40.4 \mathrm{CD}$ & $39.3 \mathrm{BCD}$ & 129 A B & 126 A B C & $120.3 \mathrm{~A}$ & $126.6 \mathrm{~A}$ \\
\hline Antjc-20 & $40.9 \mathrm{CD}$ & 39.3 BCD & $127 \mathrm{DE}$ & $124 \mathrm{C} \mathrm{D} \mathrm{E}$ & 115.6 A B & 118.6 A B C \\
\hline Antjc-23 & $40.3 \mathrm{CD}$ & 39.3 BCD & $127.3 \mathrm{CD}$ & 124.3 B C D & $101.3 \mathrm{CD}$ & 104.3 C D E F \\
\hline Antsoy-2 & $39.3 \mathrm{EF}$ & 38.3 DEF & 124.3 C D E & 121.3 C D E F & $100.3 \mathrm{CD}$ & 103.3 C D E F \\
\hline Antwa-2 & $38.9 \mathrm{~F}$ & $37.7 \mathrm{~F}$ & $119.2 \mathrm{~F}$ & $117.3 \mathrm{~F}$ & 110.3 A B C & 113.3 A B C D \\
\hline Antwa-20 & $40.0 \mathrm{DE}$ & 39.0 BCDE & $123.3 \mathrm{DE}$ & 120.3 D E F & $106 \mathrm{D} \mathrm{E}$ & 109 B C D E \\
\hline Antwa-4 & $40.3 \mathrm{CD}$ & 39.3 BCD & 125.3 C D E & 122.3 C D E F & $90.3 \mathrm{EF}$ & $95.3 \mathrm{EF}$ \\
\hline Batem-204 & $39.3 \mathrm{EF}$ & 38.3 DEF & $127 \mathrm{C} \mathrm{D} \mathrm{E} \mathrm{F}$ & $124 \mathrm{CD}$ E & $91 \mathrm{EF}$ & $95 \mathrm{EF}$ \\
\hline Batem-210 & $40.7 \mathrm{BC}$ & $39.7 \mathrm{ABC}$ & 128.6 A B C & 125.6 A B C D & $106.3 \mathrm{D}$ & 100.3 D E F \\
\hline Batem-316 & $42.7 \mathrm{~A}$ & $40.7 \mathrm{~A}$ & $131.6 \mathrm{~A} \mathrm{~B}$ & 129.6 A B & $71.3 \mathrm{I}$ & $70.3 \mathrm{HI}$ \\
\hline Göksoy & $39.0 \mathrm{~F}$ & $38.0 \mathrm{EF}$ & $121.6 \mathrm{EF}$ & 118.6 E F & $82.6 \mathrm{~F}$ & $88.6 \mathrm{~F}$ \\
\hline Kocatürk & $39.0 \mathrm{~F}$ & $38.0 \mathrm{EF}$ & 122.6 E F G & 118.6 E F & 93.6 D E & 99.6D E F \\
\hline LSD & 1.96 & 1.06 & 6.24 & 5.52 & 14.22 & 16.22 \\
\hline $\operatorname{Cv}(\%)$ & 3.69 & 1.63 & 5.61 & 2.68 & 7.63 & 9.70 \\
\hline
\end{tabular}

$* \mathrm{p}<0.05, * * \mathrm{p}<0.01$

2018 y1lında bitki boyu $(\mathrm{cm})$ değerleri ortalama 71.3-121.6 cm arasında değişmiş, aynı deneme y1lında Antjc-15 hatt1 121.6 $\mathrm{cm}$ ile en uzun bitki boyuyla istatistiksel olarak ilk grupta yer almıştır. Batem-316 hatt1 ise $71.3 \mathrm{~cm}$ ile en k1sa bitki boyuyla son grupta yer aldığı tespit edilmiştir. 2019 y1lında ise Antjc-15 hatt1 126,6 cm ile (a) grubunda yer alırken, Adasoy çeşidi 67.6 cm ortalama bitki boylarıyla (1) grubunda yer almışlardır. Her iki yılda da en uzun ve en kısa bitki boyu arasında yaklaşık 50 cm'lik bir fark bulunmuştur. Beyyavaş ve ark. (2007) 'de Harran tarımsal araştırma enstitüsü deneme alanında yaptıkları iki yıllık ikinci ürün soya denemesinde bitki 
boylarının ilk yıl 60.08-120.67 cm arasında ikinci y1l ise 56.30-108.03 cm arasında değiştiğini, Khan ve ark. (2011) Pakistan'da 20 hattın genetik varyans analizini yaptıkları çalışmada hatların ortalama boylarının 56.51 ile $106 \mathrm{~cm}$ arasında değiştiğini bildirmişlerdir. Beyyavaş ve ark. (2007), Karakuş ve ark. (2013), Malik ve ark., (2011)'nın bulgularıyla, araştırma sonucunda elde edilen sonuçların uyum içerisinde olduğu görülmektedir.

Çizelge 4. Verim, 1000 tane ağırlığ ve ilk bakla yüksekliği

\begin{tabular}{|c|c|c|c|c|c|c|}
\hline \multirow[b]{2}{*}{ Genotipler } & \multicolumn{2}{|c|}{ Verim** } & \multicolumn{2}{|c|}{1000 tane $A \breve{g}^{* *}$} & \multicolumn{2}{|c|}{ İlk Bakla Yük.* } \\
\hline & 2018 & 2019 & 2018 & 2019 & 2018 & 2019 \\
\hline Adasoy & $200.4 \mathrm{D}$ & $171.4 \mathrm{D}$ & $148.1 \mathrm{EF}$ & $143.1 \mathrm{DEF}$ & 4.1 B C D & $3.2 \mathrm{D}$ \\
\hline Antjc-14 & 297.6 C D & $239.6 \mathrm{D}$ & 155.9 B C & 152.9 B C D & $3.6 \mathrm{D} \mathrm{E}$ & $3 \mathrm{D}$ \\
\hline Antjc-15 & $548.1 \mathrm{~A}$ & $560.1 \mathrm{~A}$ & $151.9 \mathrm{~B} \mathrm{C}$ & 147.9 B C D E & $7.8 \mathrm{~A} \mathrm{~B}$ & $4.8 \mathrm{~A} \mathrm{~B}$ \\
\hline Antjc-17 & $501.2 \mathrm{~A} \mathrm{~B}$ & $531.2 \mathrm{~A} \mathrm{~B}$ & 150.1 B C D & 145.1 B C D E & $8 \mathrm{~A}$ & $7.2 \mathrm{~A}$ \\
\hline Antjc-20 & 492.1 A B C & $482.1 \mathrm{~A} \mathrm{~B}$ & $130.1 \mathrm{G}$ & 132.1 FG & 4.6 A B C & $4.8 \mathrm{~A} \mathrm{~B}$ \\
\hline Antjc-23 & 500.6 A B & 510.6 A B & 136.8 F G & $125.8 \mathrm{G}$ & 4.3 B C D & 4.6 A B C \\
\hline Antsoy-2 & 532.7 A B & 554.7 A B & 143.2 E FG & 138.2 E FG & 5.3 A B C & $4.3 \mathrm{~A} \mathrm{~B} \mathrm{C}$ \\
\hline Antwa-2 & 519.9 A B & 527.9 A B & 151.5 B C & 147.5 B C D E & 4.2 B C D & 3.9 A B C D \\
\hline Antwa-20 & 493.3 A B C & $500.3 \mathrm{~A} \mathrm{~B}$ & $179.4 \mathrm{~A}$ & $170,4 \mathrm{~A}$ & $3,5 \mathrm{CD}$ & 3,5 C D \\
\hline Antwa-4 & $509.2 \mathrm{~A} \mathrm{~B}$ & $505.2 \mathrm{~A} \mathrm{~B}$ & $161.1 \mathrm{~A} \mathrm{~B}$ & 157.1 A B C & 3.8 B C D & $3.8 \mathrm{~B} \mathrm{C} \mathrm{D}$ \\
\hline Batem-204 & 491.9 A B C & 494.9 A B & 145.1 E F G & 141.1 D E F & 4.6 A B C & $4.3 \mathrm{~A} \mathrm{~B} \mathrm{C}$ \\
\hline Batem-210 & 490.8 A B & 499.8 A B & 151.4 B C & 148,4 B C D E & 4,1 B C D & 4.3 A B C \\
\hline Batem-316 & $238.1 \mathrm{D}$ & $297.1 \mathrm{CD}$ & 143.9 E F G & 139.9 D E F & $3.1 \mathrm{DEF}$ & $3.1 \mathrm{D}$ \\
\hline Göksoy & 488.2 A B C & 494.2 A B & 146.8 D E F & 143.8 C D E F & $4.2 \mathrm{~A} \mathrm{~B} \mathrm{C}$ & 4,3 A B C \\
\hline Kocatürk & 419.9 B C & 422.9 B C & $162.2 \mathrm{~A} \mathrm{~B}$ & $158.2 \mathrm{~A} \mathrm{~B}$ & 3.9 B C D & $3.8 \mathrm{~B} \mathrm{C} \mathrm{D}$ \\
\hline LSD & 121.6 & 136,6 & 16,94 & 13,94 & 1,22 & 1,18 \\
\hline $\mathrm{Cv}(\%)$ & 12.07 & 13.52 & 8,72 & 5,71 & 11,76 & 17,49 \\
\hline
\end{tabular}

${ }^{*} \mathrm{p}<0.05,{ }^{* *} \mathrm{p}<0.01$

Çizelge 4.'de 2018 yılı ortalamaları ve LSD gruplandırması incelendiğinde, 2018 y1lında tohum verimi $\left(\mathrm{kg} \mathrm{da}{ }^{-1}\right)$ değerleri 200.4-548.1 $\mathrm{kg} \mathrm{da}^{-1}$ arasında değişmiş, 2016 y1lında tohum verimi $\left(\mathrm{kg} \mathrm{da}{ }^{-1}\right)$ değerleri

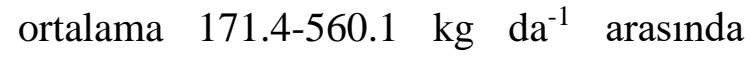
değiştiği görülmektedir. KA08-06 nolu hat ise $369.86 \mathrm{~kg}$ da-1 ile istatistiksel olarak ilk grupta yer alırken. Her iki yılda da Antjc-15 hattından en yüksek tohum verimi elde edilirken, Adasoy çeşidi her iki deneme y1lında da istatistiksel olarak son grupta yer almıştır. Kınacı (2011) Çanakkale koşullarında 134.2-405.9 $\mathrm{kg} \mathrm{da}^{-1}$ arasında değiştiğini, Acar (2014) Kahramanmaraş ikinci ürün koşullarında 192-319 $\mathrm{kg} \mathrm{da}^{-1}$ arasında değiştiğini, Dolapçı (2012) Kahramanmaraş’ta yaptığı çalışmada soyada tohum veriminin 260.87-376.96 kg $\mathrm{da}^{-1}$ arasında değiştiğini bildirmiştir. Yapılan çalışmada kullanılan hatlar diğer araştırmacıların kullandığ 1 genotiplerden 
daha yüksek tohum verimine sahip olduğu gözlemlenmiştir. Çizelge 4.'de genotip ortalamaları ve LSD gruplandırması incelendiğinde, 2018 yllında bin tohum ağırlığı (g) değerleri 130.1-179.4 g arasında değişmiş, 2019 y1lında genotiplerin bin tohum ağırlığı (g) değerleri ortalama 125.8$170.4 \mathrm{~g}$ arasında değişmiştir. Her iki yılda da 1000 tohum ağırlığı en yüksek hat Antwa-20 hattı olurken, 2018 yilında en düşük 1000 tane ağılığı Antjc-20’den 2019 y1lında ise Antjc-23'den elde edilmiştir. Soya bitkisinde bin tohum ağırlığı, genotip, çevre koşulları, ekim zamanı, kültürel bakım işlemleri gibi değişik faktörlerden etkilenen ve verimi belirleyen en önemli ölçütlerden biridir. Soyada tohum iriliğinin genotiplere göre önemli derecede değişiklik gösterebilen bir özellik olduğunu bildirilmişlerdir (Arığlu ve ark. 1992). Beyyavaş ve ark. (2007) 'de Şanlıurfa Harran Ovası Tarımsal Araştırma Enstitüsü deneme alanında yaptıkları iki yıllık ikinci ürün soya ekim zamanı denemesinde bin tohum ağırlığının ilk yıl 129.67-170.00 g arasında ikinci yıl ise 144.67-178.33 g arasında değiştiğini bildirdikleri çalışma ile bulgularımız arasında kısmi uyum olduğu görülmüştür.
Çizelge 4. incelendiğinde; denemeye konu olan soya genotiplerinin ilk bakla yükseklikleri bakımından farklılıklar her iki yılda da istatistiksel açıdan önemli ( $\mathrm{p}<$ 0.01) seviyesinde önemli bulunmuştur. 2018 y1lı ortalamaları ve LSD gruplandırması incelendiğinde, 2018 yılında ilk bakla yüksekliği (cm) değerleri $3.1-8 \mathrm{~cm}$ arasında değişmiş, 2016 yılında ilk bakla yüksekliği değerleri ortalama 3.1-7.6 $\mathrm{cm}$ arasında değişmiştir. Her iki yılda dayılında Antjc-17 hattı ilk grupta yer aldı ğ 1 , Batem-316 hattı ise yaklaşık $3 \mathrm{~cm}$ ile son grupta yer aldığı görülmektedir. İlk bakla yüksekliğini etkileyen faktörlerin başında genetik farklılığın geldiği bilinmekle birlikte, ekim zamanının geciktirilmesi ilk baklaların zemine daha yakın olduğu tespit edilmiştir (Akkoyunlu, 1979). Soya da ilk bakla yüksekliği makinalı hasattaki verim kaybının en az seviyelerde tutulması bakımından önem arz etmektedir. Civelek (2006) Samsun'da yaptığı araştırmada ilk bakla yüksekliğinin 3.95 ile $8.81 \mathrm{~cm}$ arasında değiştiğini, Arslan (2007) ilk bakla yüksekliğinde değişim aralığının ana üründe $10.3-22.8 \mathrm{~cm}$, ikinci üründe 4.3 ile $9.3 \mathrm{~cm}$ arasında değiştiğini bildirmiştir. 
Çizelge 5. Ham protein ve ham yağ özellikleri

\begin{tabular}{|c|c|c|c|c|}
\hline \multirow{2}{*}{ Genotipler } & \multicolumn{2}{|c|}{ Ham protein** } & \multicolumn{2}{|c|}{ Ham yağ*** } \\
\hline & 2018 & 2019 & 2018 & 2019 \\
\hline Adasoy & $34.1 \mathrm{BC}$ & $34.9 \mathrm{BCDE}$ & $18,3 \mathrm{C} \mathrm{D}$ & $19,7 \mathrm{ABCD}$ \\
\hline Antjc-14 & $37.3 \mathrm{~A} \mathrm{~B}$ & 36.8 A B C D & $17.9 \mathrm{CDE}$ & $18.8 \mathrm{C} \mathrm{D} \mathrm{E}$ \\
\hline Antjc-15 & $33.1 \mathrm{C} \mathrm{D} \mathrm{E}$ & 35.4 A B C D E & 19.6 B C D & 19.3 B C D E \\
\hline Antjc-17 & $30.2 \mathrm{EF}$ & $33.2 \mathrm{EF}$ & 19.5 B C D & 19.6 B C D E \\
\hline Antjc-20 & $27.8 \mathrm{G}$ & $28.9 \mathrm{G}$ & $23.6 \mathrm{~A}$ & $21.2 \mathrm{~A}$ \\
\hline Antjc-23 & $29.1 \mathrm{~F}$ & $31.6 \mathrm{FG}$ & $18.2 \mathrm{C} \mathrm{D} \mathrm{E}$ & 19.9 A B C \\
\hline Antsoy-2 & $31.5 \mathrm{DEF}$ & $33.7 \mathrm{DEF}$ & $21.1 \mathrm{~A} \mathrm{~B}$ & 20.4 A B \\
\hline Antwa-2 & 36.9 A B & 37.8 A B & $18.1 \mathrm{E}$ & $18.3 \mathrm{DE}$ \\
\hline Antwa-20 & $39.9 \mathrm{~A}$ & $38.3 \mathrm{~A}$ & $17.9 \mathrm{DE}$ & 18.6 C D E \\
\hline Antwa-4 & $35.1 \mathrm{~B} \mathrm{C}$ & 37.2 A B C & 19.1 C D & 18.7 C D E \\
\hline Batem-204 & 36.2 A B C & $34.2 \mathrm{C} \mathrm{D} \mathrm{E} \mathrm{F}$ & 19.1 A B C & 19.9 A B C \\
\hline Batem-210 & 36.6 A B C & 36.1 A B C D E & $18.6 \mathrm{D} \mathrm{E}$ & $18.2 \mathrm{DE}$ \\
\hline Batem-316 & 34.8 A B C & 35.9 A B C D E & $18.3 \mathrm{DE}$ & $18.0 \mathrm{E}$ \\
\hline Göksoy & 37.1 A B C & 36.3 A B C D E & 19.2 B C D & 18.7 C D E \\
\hline Kocatürk & 34.9 A B C D & 35.6 A B C D E & 18.1 C D E & 18.4 C D E \\
\hline LSD & 2.99 & 3.19 & 1.12 & 1.59 \\
\hline $\mathrm{Cv}(\%)$ & 8.62 & 5.44 & 3.36 & 4.98 \\
\hline
\end{tabular}

Çizelge 5.'da 2018 yılı ortalamaları ve LSD gruplandırması incelendiğinde, 2018 y1lında ham protein (\%) değerleri 27.8-39.9 arasında değişmiş, 2019 yılında ortalama ham protein (\%) değerleri 28.9-38.3 arasında değişmiştir. Her iki yılda da Antwa-20 hatt1 $2018 \% 39.9$ ve 2019 yılında \% 38.3 ham protein içeriği oranı ile istatistiksel olarak ilk grupta yer alırken, Antjc-20 2018 yılında \% 27.82019 yılında ise \% 28.9 ham yağ oranlarıyla istatistiki olarak son grupta yer almışlardır. Araştırmamız sonucunda elde edilen tohuma ait protein oranı (\%) değerleri bazı araştırmacıların (Önder ve Akçin, (1991), Civelek, (2006), Güneş, (2006), Ünal
(2007), Beyyavaş ve ark., (2007), Öden, (2012), Öztürk, (2015), Candoğan ve Yazgan, (2016) sonuçlarından yüksek çıkarken, bazılarından düşük (Onat, 2012), Bellaloui ve ark. (2011), bazı araştırmacıların bulgularıyla (Söğüt ve ark., (2005), Yetgin, (2008) uyum içerisindedir. Çizelge 5.'de 2018 yılı ortalamaları ve LSD gruplandırmaları incelendiğinde, 2018 y1lında ham yağ (\%) değerleri 18.1-23.6 arasında değişmiş, 2019 yılında ortalama ham yă̆ oranı (\%) değerleri 18.0-21.2 arasında değişmiştir. Civelek (2006) \% 20.04-23.69 arasında yağ oranlarıyla bizim çalışmamızdan yüksek yağ oranları elde edilmiştir. Kara ve ark. (1987) \% 14.1-17.4, 
Börtüçene (2002) \% 16.4-17.9 arasında Ünal (2007) \% 18.45- 21.40 Öden (2012) \% 16.00-25.75 arasında ham yağ oranı elde ederek bizim araştırma sonuçlarımızın altında kalmışlardır.

\section{SONUÇ}

Soyada kurumsal olarak kamu ve özel sektörün elindeki imkânların kısıtlı oluşu seleksiyon aşamalarında yalnız fenotipik bazı kriterler üzerine durulması sonucunu beraberinde getirmektedir. $\mathrm{Bu}$ durumda çoğu kez boy, bakla sayısı ve gövde yapısı gibi gözlemlenebilir ölçütler bakımından vasat fakat kalite kriterleri diye tabir edilen protein oranı ve yă̆ verimi gibi özellikler açısından nisbeten iyi durumdaki birçok genotip veya hat elimine edilebilmektedir. İşte bu tür durumların önüne geçilebilmesi amacıyla yapılmış olan çalışmamıza ek olarak moleküler markırlar kullanarak genetik faktörlerinde soya 1slah çalışmalarına entegre edilmesi gerekmektedir. Klasik ıslah çalışmalarının daha k1sa sürede ve hedef odaklı olabilmesi için fizyolojik ve morfolojik parametrelerin yanında laboratuvar çalışmalarının da eklenmesi göz ardı edilemez bir zorunluluk durumundadır. Gelecekte soya 1slah çalışmalarına eklenmesi gereken diğer bir gereksinim ise ebeveynlerin hastalıklara dayanıkl111k

karekterizasyonun yapılmasıdır. Tarla ve laboratuvar çalışmalarıyla soya da problem olan hastalıklara tolerant çeşitlerin geliştirilmesi bu sayede olabilecektir.

\section{KAYNAKÇA}

Acar, N. 2014. Değişik kökenli farklı soya [Glycine $\max$ L. Merrill.] çeşitlerinin Kahramanmaraş koşullarında ana ürün ve II. ürün olarak verim ve kalite özelliklerinin belirlenmesi. Kahramanmaraş Sütçü İmam Üniversitesi, Fen Bilimleri Enstitüsü, Yüksek Lisans Tezi, Kahramanmaraş, 92s

Akkoyunlu, N. 1979. Soya fasulyesinde uygun ekim zamanının tespiti. Karadeniz Bölge Zirai Araştırma Enstitüsü Yayınları, Samsun, 16s.

Arığlu, H. Arslan, M., İşler, N. 1992. Çukurova koşullarında II. ürün olarak yetişen bazı soya çeşitlerinin önemli tarımsal ve bitkisel özelliklerinin belirlenmesi. Çukurova Üniversitesi Ziraat Fakültesi Dergisi, 7(3): 191-206.

Arığlu, H. 2000. Yağ bitkileri yetiştirme ve 1slahı. Ç.Ü. Ziraat Fak. Genel Yayın No:220, Ders Kitapları Yayın No: A70, Adana.

Arslan, D. 2007. Soyada (Glycine max (L.) Merll), ana ve ikinci ürün ekim zamanlarında yapılan seleksiyonların verim ve verim öğelerine etkileri. On Dokuz Mayıs Üniversitesi, Fen Bilimleri Enstitüsü, 
Yüksek Lisans Tezi, Samsun, 52s.

Bellaloui, N., Reddy, K.N., Gillen, A.M., Fisher, D.K., MengIstu, A. 2011. Influence of planting date on seed protein, oil, sugars, minerals, and nitrogen metabolism in soybean under irrigated and non-1rrigated environments. American Journal of Plant Sciences, 2(5): 702-715.

Beyyavaş, V., Haliloğlu, H., Yılmaz, A. 2007. İkinci ürün soya tarımında farklı ekim zamanlarının verim ve verim unsurlarına etkisi. Harran Üniversitesi, Ziraat Fakültesi Dergisi, 11(37/4): 23-32.

Börtüçene, O. 2003. II. Ürün tarımına uygun bazı soya (Giycine max.) çeşitlerinin verim ve kalite özellikleri ile bu özellikler arasındaki ilişkilerin belirlenmesi üzerine bir araştırma. Harran Üniversitesi, Fen Bilimler Enstitüsü, Yüksek Lisans Tezi, Şanlıurfa,75s.

Candoğan, B. N., Yazgan, S. 2016. Yield and quality response of soybean to full and deficit irrigation at different growth stages under sub-humid climatic conditions. Tarım Bilimleri Dergisi, 22(2): 129-144.

Civelek, T. 2006. Yapraktan demir uygulamasının bazı soya (Glycine max L.) çeşitlerinde verim ve verim unsurları ile önemli kalite özelliklerine etkisi. Ondokuz Mayıs Ünivetsitesi, Fen Bilimleri Enstitüsü, Yüksek Lisans Tezi, Samsun, 57s.
Cober, E., Voldeng, H.D. 2000. Developing high-protein, high-yield soybean populations and lines. Crop Science, 40(1): 39-42.

Çetin, S.H. 2010. Soyada bakteri aşılaması ve fosfor uygulamalarının verim ve kalite üzerine etkileri. Selçuk Üniversitesi, Fen Bilimleri Enstitüsü, Yüksek Lisans Tezi, Ankara, 58s.

Çopur, O., Gür, M.A., Demirel, U., Karakuş, M. 2009. Performance of some soybean [Glycine max (L.) Merr.] genotypes double cropped in semi-arid conditions. Notulae Botaniae Horti Agrobotanici Cluj-Napoca, 37(2): 85-91.

Dolapçı, F. 2012. Kahramanmaraş koşullarında bazı soya [Glycine max L. (Merill)] çeşitlerinin verim ve verim unsurlarının belirlenmesi. Kahramanmaraş Sütçü İmam Üniversitesi, Fen Bilimleri Enstitüsü, Yüksek Lisans Tezi, Kahramanmaraş, 45s.

Erdoğmuş, M. 2007. Soya fasulyesi (Glycine Max (L.) Merr.)' nde erkenci genotipler için seleksiyonda dikkate alınacak agronomik özelliklerin belirlenmesi. Ondokuz Mayıs Üniversitesi. Fen Bilimleri Enstitüsü, Yüksek Lisans Tezi, Samsun, 45s.

Güneş, A. 2006. İkinci ürün soya (Glycine $\max (\mathrm{L}$.$) Merll ] tarımında farklı$ 
azot doz ve uygulama zamanlarının verim ve verim unsurlarına etkisi. Harran Üniversitesi, Fen Bilimleri Enstitüsü, Yüksek Lisans Tezi, Şanlıurfa, 60s.

Kara, K., Oral E., Günel, E. 1987. Erzurum ekolojik koşullarında bazı soya çeşitlerinin fenolojik, morfolojik özellikleri ile verim ve verim öğeleri üzerine bir araştırma. Türk Tarım ve Ormancılık Dergisi, Cilt.12 s.3.

Karakuş, M., Arslan, H., Hatipoğlu, H., Rastgeldi, U. 2013. Harran ovas1 koşullarına uygun ana ve ikinci ürün bazı soya hat ve çeşitlerinin belirlenmesi. Türkiye X. Tarla Bitkileri Kongresi, 10-13 Eylül, Konya, Cilt I, s.952-958.

Khan, S., Latif, A., Ahmad, S.Q., Ahmad, F., Fida, M. 2011. Genetic variability analysis in some advanced lines of soybean (Glycine max L. Merr.). Asian Journal of Agricultural Sciences, 3(2): 138141.

Kınac1, M. 2011. Çanakkale koşullarında soya fasulyesi çeşitlerinin verim ve bazı kalite unsurlarının belirlenmesi. Selçuk Üniversitesi, Fen Bilimleri Enstitüsü, Yüksek Lisans Tezi, Konya, 69s.

Kolay, B. 2007. Diyarbakır koşullarında II. ürün soya tarımında farklı toprak işleme yöntemlerinin verim ve bazı toprak özelliklerine etkisi. Harran Üniversitesi,
Fen Bilimleri Enstitüsü, Yüksek Lisans Tezi, Şanlıurfa, 66s.

Malik, M.F.A., Ashraf, M., Qureshi, A.S., Khan, M.R., 2011. Investigation and comparison of some morphological traits of the soybean populations using cluster analysis. Pakistan Journal of Botany, 43(2): 1249-1255.

Onat, B.Z.F. 2012. Erken ve geç ekilen ikinci ürün soyada çift sıralı ekim yönteminde farklı bitki yoğunluklarının verim ve verim unsurlarına etkisi. Çukurova Üniversitesi, Fen Bilimleri Enstitüsü, Doktora Tezi, Adana, 134s.

Öden, E. 2012. Soya bitkisinde bakteri aşılaması, fosfor ve demir uygulamalarının nodulasyon ve $\mathrm{n}_{2}$ fiksasyonuna etkisi. Mustafa Kemal Üniversitesi, Fen Bilimleri Enstitüsü, Yüksek Lisans Tezi, Antakya/Hatay, 119s.

Önder, M., Akçin, A. 1991. Çumra ekolojik şartlarında nodozite bakterisi (Rhizobium japonicum) ile farklı seviyelerde azot kombinasyonları uygulanan soya çeşitlerinde tane, yağ ve protein verimi ile verim unsurları arasındaki ilişkiler üzerine bir araştırma. Turkish Journal of Agriculture and Forestry, 15: 765-776.

Önemli, F., Atakişi, İ.K. 2001. Soya [Glycine Max (L.) Merill] çeşit ve hatları 
üzerinde olgunlaşma gün sayısı ile diğer verim ve kalite unsurları arasındaki ikili ilişkilerin belirlenmesi üzerine bir araştırma. Trakya Üniversitesi, Tekirdağ Ziraat Fakültesi, Türkiye 4. Tarla Bitkileri Kongresi, 17-21 Eylül, Cilt II Endüstri Bitkileri, Tekirdağ, s.355-359.

Öztürk, F. 2015. Toprak işleme yöntemleri ve bitki sıklıklarının ana ve ikinci ürün olarak yetiştirilen soya [Glycine $\max ($ L.) Merrill]'nin büyüme - gelişme ve tohum verimi üzerine etkileri. Dicle Üniversitesi, Fen Bilimleri Enstitüsü, Doktora Tezi, Diyarbakır, 199s.

Poehlman, J.M. 1979. Breeding Field Crops, 2nd edition, The Avi Publishing Company, Inc., Connecticut, 483s.

Sögüt, T., Arıoğlu, H. H., Çubukçu, P. 2001. Farklı olgunlaşma grubuna giren bazı soya çeşitlerinin ikinci ürün koşullarında önemli tarımsal özellikleri ile bu özellikler arasındaki ilişkilerin belirlenmesi. Soya Üretimi ve Sorunları Semineri Bildirisi, Hatay, 23 Mayıs 1982.

Sögüt, T. 2005. Aş1lama ve azotlu gübre uygulamasının bazı soya çeşitlerinin verim ve verim özelliklerine etkisi. Akdeniz Üniversitesi, Ziraat Fakültesi Dergisi, 18(2): 213-218.
Uncu Arslantaş H, Arığlu H.H. 2005. İkinci ürün soya tarımında farklı ekim zamanlarına göre bazı büyüme düzenleyicilerin verim ve kalite üzerine etkileri. Türkiye VI. Tarla Bitkileri Kongresi, 5-9 Eylül, Antalya (Araştırma Sunusu Cilt I, Sayfa 375-380).

Ünal, İ. 2007. Melezleme yöntemiyle elde edilen soya [Glycine max (L.) Merr.] hatlarının bazı tarımsal özelliklerinin belirlenmesi. Selçuk Üniversitesi, Fen Bilimleri Enstitüsü, Yüksek Lisans Tezi, Konya, 54s.

Wigham, D.K., H.C. Minor. 1978. Agronomic Characteristics and Enviromental Stres. Soybean Physiology, Agronomy and Utilization (Ed.by A.G.Norman). Academic Pres. London. 249 p.

Yetgin, S. G. 2008. Çukurova bölgesinde ana ürün koşullarında bazı soya çeşit ve hatlarının verim ve tarımsal özelliklerinin belirlenmesi. Çukurova Üniversitesi, Fen Bilimleri Enstitüsü, Yüksek Lisans Tezi, Adana, 56s. 
Yılmaz, A., Beyyavaş, V., Cevheri, İ., Haliloğlu, H. 2005. Harran ovası ekolojisinde ikinci ürün olarak yetiştirilebilecek bazı soya [Glycine max. L. Merrill.] çeşit ve genotiplerinin belirlenmesi. Harran Üniversitesi, Ziraat Fakültesi Dergisi, 9(2): 55-61.
Zhang, L., Wang, R., J. D. Hesketh. 2001. Effects of photoperiod on growth and development of soybean floral bud in different maturity. Agronomy Journal, 93: 944-948. 